Jurnal PG-PAUD Trunojoyo : Jurnal Pendidikan dan Pembelajaran Anak Usia Dini, Volume 7, Nomor 1, April 2020, hal $10-16$, ISSN : 2528-3553 (online), ISSN: 2407-4454 (print)

\title{
EFEKTIFITAS PENGGUNAAN BUKU CERITA BERGAMBAR TERHADAP KECERDASAN VISUAL ANAK PRASEKOLAH
}

\author{
Eka Mei Ratnasari \\ Program Studi Pendidikan Guru Pendidikan Anak Usia Dini, Institut Agama Islam Negeri Metro \\ Lampung \\ email: ekameiratnasari1@gmail.com
}

Received (Bulan Januari 2020), Accepted (Bulan Februari 2020), Published (Bulan April 2020)

\begin{abstract}
The Effectiveness of Using A Story Book with Picture through Visual Intelligence Preschool Children. Multiple intelligences must be optimally stimulated. Its development will be very good for the development of early childhood abilities. This research will discuss the effectiveness of the use of picture books on preschool children's visual intelligence. The research aims to look for the effectiveness of the use of picture books on children's visual intelligence aged of 4-5 years. This study used quasi-experiment method. The subjects were children of TK-KB ABA Pringwulung, Yogyakarta. The sampling technique uses purposive sampling, including two groups, Al as the experimental group and A2 as the control group. The subjects used in this study examined 40 children. The data analysis technique used a t-test using the SPSS for Windows version 16 computer program to see children's visual intelligence between the two cohorts. The results indicated that there was a significant impact on children's visual intelligence through the use of picture book media in group A at $T K-K B$ ABA Pringwulung Yogyakarta. It can be used by parents, educators, and educational practitioners so as to build an appropriate strategy in developing early childhood visual intelligence.
\end{abstract}

Keywords: Visual Intelligence, Picture book, Pre-school children

\begin{abstract}
Absrak: Efektivitas Penggunaan Buku Cerita Bergambar terhadap Kecerdasan Visual Anak Prasekolah. Kecerdasan jamak harus distimulasi secara optimal, pengembangannya akan sangat baik bagi perkembangan kemampuan anak usia dini. Penelitian ini akan mengkaji tentang kefektifan penggunaan buku cerita bergambar terhadap kecerdasan visual anak prasekolah. Penelitian ini bertujuan untuk mengetahui keefektifan penggunaan buku cerita bergambar terhadap kecerdasan visual anak usia 4-5 tahun. Jenis penelitian yang digunakan dalam penelitian ini adalah quasi-eksperimen. Subjek penelitian dalam penelitian ini adalah anak kelompok A TK-KB ABA Pringwulung Yogyakarta. Teknik pengambilan sampel menggunakan purposive sampel. Terdapat dua kelompok yakni kelompok A1 yang menjadi kelompok eksperimen dan A2 merupakan kelompok kontrol. Subjek yang digunakan dalam penelitian ini berjumlah 40 anak. Teknik analisis data menggunakan uji t-test menggunakan program komputer SPSS for Windows versi 16 untuk melihat kecerdasan visual anak diantara kedua kelompok. Hasil penelitian menunjukkan bahwa terdapat pengaruh signifikan terhadap kecerdasan visual anak melalui penggunaan media buku cerita bergambar pada kelompok A di TK-KB ABA Pringwulung Yogyakarta. Penelitian ini dapat digunakan oleh orangtua, guru, maupun praktisi pendidikan sehingga dapat memberikan stimulasi yang optimal dalam perkembangan kecerdasan visual anak usia dini
\end{abstract}

Kata kunci: Buku cerita bergambar, Kecerdasan visual, Anak usia prasekolah 
Jurnal PG-PAUD Trunojoyo : Jurnal Pendidikan dan Pembelajaran Anak Usia Dini, Volume 7, Nomor 1, April 2020, hal $10-16$, ISSN : 2528-3553 (online), ISSN: 2407-4454 (print)

\section{PENDAHULUAN}

Pendidikan menjadi fondasi penting bagi anak usia din. Usia dini sering disebut dengan masa yang tepat dalam mengoptimalkan berbagai potensi anak seperti aspek fisik \& motorik, bahasa, kognitif, sosial-emosional, nilai agama dan moral serta seni. Anak memiliki kecenderungan unuk meniru banyak hal yang ada di sekitarnya. Anak terbiasa meniru apa yang dilihat, didengar dan dirasakan. Anak juga terlahir dengan kemampuan dan potensi yang berbeda-beda, serta memiliki kelebihan dan bakat masing-masing (Suyanto, 2005). Kecerdasan diartikan sebagai kemampuan dalam memecahkan masalah, menghasilkan karya yang merupakan dampak dari bermasyarakat (Gardner 1993).

Kecerdasan jamak mecakup sembilan kecerdasan, sembilan kecerdasan ganda tersebut adalah linguistik, matematis, visualspatial, kinestetik, musical, intrapersonal, interpersonal, dan eksistensial. Jika kecerdasan anak distimulasi dengan baik, maka akan berpengaruh pada kemampuan anak dalam memecahkan masalah ataupun anak dapat memberikan solusi dari suatu kejadian yang terjadi.

Salah satu dari sembilan kecerdasan jamak adalah kecerdasan visual. Kecerdasan visual merupakan kecerdasan yang mampu melihat suatu objek dengan sangat teliti/detail. Suyadi (2010) mengatakan bahwa orang yang memiliki kecerdasan ini akan mampu merekam benda yang dilihat dan didengar ke dalam memori otak dalam jangka waktu yang lama. Musfiroh (2005) memaparkan bahwa kecerdasan visual-spasial diartikan sebagai kemampuan menilai tentang dunia tata ruang secara akurat serta mentransformasikan persepsi visual-spasial tersebut dalam berbagai bentuk. Selain itu, Julli (2014) menyebutkan bahwa aspek dari kecerdasan visual mencakup kepekaan terhadap bentuk, unsur bentuk, ukuran, komposisi, dan warna. Anak yang cerdas visual akan berpikir imajinatif serta mampu membayangkan sesuatu dengan detail, kemudian senang membuat kontruksi tiga dimensi dari unsur, seperti: lego, brick, bombiq, dan balok dan juga mereka belajar dengan melihat dan mengamati benda, bentuk dan warna.

Kemampuan visual digunakan dalam kehidupan sehari-hari seperti menggambar, menjahit, maupun mewarnai gambar.
Berdasarkan hasil observasi, peneliti menemukan bahwa terdapat anak yang masih kesulitan dalam mengelompokan geometri, kesulitan dalam menggambar dan mengingat objek yang dilihat. Kebanyakan pendidik lebih fokus dalam mengembangkan kemampuan kognitif dan fisik motorik khusunya pada kemampuan membaca, menulis dan berhitung.

\section{Kecerdasan Visual}

Orang yang memiliki kecerdasan visual memiliki kecenderungan berpikir seperti penggunaan objek visual berupa film, video , gambar, dan peragaan yang menggunakan model maupun slide. Masa kanak-kanak merupakan waktu yang tepat dalam mengembangkan kecerdasan visual anak (Lucy, 2010). Brewer (2007) menjelaskan bahwa kecerdasan visual sangat bermanfaat dalam berbagai pekerjaan, serta berkaitan dengan berbagai disiplin ilmu. Hampir semua pekerjaan ataupun kegiatan memerlukan kecerdasan spasial.

Kecerdasan visual menjadi salah satu di antara sembilan kecerdasan majemuk. Kecerdasan ini ditandai dengan kepekaan anak terhadap warna, garis, bentuk, ruang, dan hubungan yang ada antara elemen-elemen ini, (Armstrong, 2009). Pengertian lain, kecerdasaan visual merupakan kemampuan merancang dan memakai bentuk dalam ruang (Williams, 2002). Kecerdasan visual adalah kemampuan dalam melihat suatu objek dari berbagai persepsi. Kecerdasan visual dapat dideteksi sedini mungkin. Hal ini dapat dilakukan dengan mengamati ciri-ciri yang tampak dari kecerdasan visual anak seperti: dapat mengingat jalan yang pernah dilewati, tidak banyak bicara tetapi lebih aktif mengerjakan hal yang berkaitan dengan abstraksi ruang, bermain bentuk dan ruang, senang mengukur (ukuran panjang, pendek, besar, kecil, jauh, dekat).

$$
\text { Suyadi (2010) menyebutkan }
$$

karakteristik anak dengan kecerdasan visual tinggi adalah sebagai berikut: 1) mampu menghitung dengan cara mengawang, 2) mampu membuat benda seperti yang tergambar dalam pikirannya, 3) mampu mengarang cerita pendek. Selain itu, terdapat indikator dalam menilai kecerdasan visual anak usia 4-5 tahun yang dijelaskan oleh Yus (2011) yaitu:

1) Menyusun lebih dari empat objek benda dalam satu ruang, contonya menata meja 
Jurnal PG-PAUD Trunojoyo : Jurnal Pendidikan dan Pembelajaran Anak Usia Dini, Volume 7, Nomor 1, April 2020, hal $10-16$, ISSN : 2528-3553 (online), ISSN: 2407-4454 (print)

dan kursi dalam kelas, merapihkan buku, menata mainan.

2) Mengisi pola yang lebih rumit, contohnya meronce.

3) Membentuk beberapa bentuk yang diketahui, seperti membentuk bola menggunanakan playdough.

4) Menggambar objek sesuai imajinasi, contohnya menggambar pemandangan atau menggambar anggota keluarga.

5) Menjahit bentuk yang lebih detail, contohnya mengikat dengan tali-temali, ataupun menganyam.

6) Memakai alat seni sederhana, contohnya memainkan alat musik sederhana.

Lingkungan belajar anak harus mendukung kecerdasan visual dari berbagai macam sisi. Kemampuan berpikir visual adalah kemampuan dalam berpikir spasial melalui berbagai bentuk (Sonawat \& Gogri via Yaumi, 2012). Kecerdasan visual mencakup potensi individu melihat suatu objek secara akurat dan teliti, anak-anak mampu melihat bentuk-bentuk gambar dibandingkan melihat pada kata-kata /tulisan. Sehingga perlu adanya penanganan seksama terkait kecerdasan visual anak.

\section{Buku Cerita Bergambar}

Secara umum, buku cerita bergambar merupakan perpaduan antara gambar dan tulisan. Kombinasi yang baik sangat diperlukan dalam buku cerita, sehingga pesan dalam buku dapat tersampaikan. Buku cerita terdiri dari 32 halaman, didalamnya terdapat gambar maupun tulisan/kata-kata yang bertujuan dalam penyampaian informasi (Tompkins \& Hoskissom, 1995). Unsur dalam sebuah cerita yang diperuntukan untuk anak yaitu membangun fiksi. Tokoh, tema, alur dan setting/tempat, sudut pandang, amanat, serta kebahasaan agar mudah dipahami oleh anak (Musfiroh, 2005).

Perkembangan kemampuan bahasa menjadi hal penting yang harus diperhatikan pada anak usia dini. Salah satu kegiatan yang dapat mengembangakan kemampuan bahasa anak adalah melalui kegiatan memabaca. Kebiasaan dalam membaca merupakan hal yang baik bagi anak. Scull, et al. (2013) pembahasan seputar buku yang dibaca merupakan hal utama dalam pembelajaran bahasa. Mitchell (2003) menjelaskan bahwa semua gambarnya dapat terlihat secara keseluruhan sedangkan teks/tulisan pada buku terlihat hanya sedikit. Bower (2014) menjabarkan bahwa buku cerita bergambar didefinisikan sebagai buku yang memuat gambar dan tulisan atau kata. Buku cerita bergambar memiliki lebih banyak gambar dibandingkan komponen tulisan (Biddle: 2014). Pemaparan serupa disampaikan oleh Mitchell (2003) tentang buku cerita bergambar dapat terlihat gambarnya secara keseluruhan, sementara teks pada buku bergambar terlihat sedikit.

Buku cerita memberikan kesempatan pada anak untuk mengembangkan kosakatanya sehingga kemampuan bahasa anak dapat berkembang optimal. Gambaran visual merupakan penentu kuat atau tidaknya pesan yang akan dikomunikasikan dalam sebuah buku cerita (Mallett, 2010). Sebagai pendidik harus memahami bahwa bercerita menggunakan buku cerita bergambar membantu mengembangkan kosakata, phonologi serta meningkatkan pengenalan huruf pada anak (Machado: 2013). Pendapat serupa tentang intervensi dalam kegiatan membaca buku secara bersama-sama dapat meningkatkan perkembangan kosakata anak (Lenhart, et al., 2017).

Buku cerita adalah salah satu media yang dapat digunakan dalam perkembangan kemampuan anak. Media gambar dapat memperkuat daya ingat serta mudah memahami tema/isi cerita. Pemaparan tersebut didukung oleh Toha-sarumpaet (2010), buku yang memaparkan sebuah cerita menggunakan gambar disebut dengan buku cerita bergambar. Buku cerita bergambar di dalamnya terdapat berbagai macam desain dan memiliki warna yang menarik. Mantei \& Kervin (2014) memaparkan terkait buku cerita bergambar adalah bentuk seni visual dan mudah digunakan anak dalam bereksplorasi.

Buku cerita bergambar dapat menjadi media dalam mengembangkan kecerdasan visual anak. Reed et al. (2015) memaparkan bahwa kegiatan bercerita melalui penggunaan buku cerita bergambar bersama teman-teman, dapat menstimulasi dalam perkembangan nalar/pemahaman anak usia empat hingga enam tahun. Cerita yang hanya berisi teks/tulisan saja, tentu hal tersebut akan sulit dipahami oleh anak usia dini, oleh sebab itu, komposisi antara gambar dan tulisan harus tepat dalam sebuah penyajian buku cerita bergambar. Pemaparan senada disampaikan oleh Lukens (2003) tentang gambar yang terdapat dalam buku membuat anak memahami 
Jurnal PG-PAUD Trunojoyo : Jurnal Pendidikan dan Pembelajaran Anak Usia Dini, Volume 7, Nomor 1, April 2020, hal $10-16$, ISSN : 2528-3553 (online), ISSN: 2407-4454 (print)

cerita dalam satu kali melihat, apabila anak melihat tulisan saja maka anak akan memahami isi cerita secara bertahap.

Secara umum, buku cerita merupakan pilihan yang banyak dipilih orangtua untuk anaknya dibandingkan dengan penggunaan gawai/gadget. Senada dengan hal tersebut, Kotaman \& Balci (2016) menjelaskan bahwa buku cerita merupakan buku yang dipilih oleh orang tua untuk anak-anaknya. Anak akan diajak untuk menghubungkan apa yang telah diceritakan maupun yang dibaca melalui penggunaan ilustrasi yang terdapat dalam buku. Anak dapat mendalami tokoh yang terdapat dalam cerita dengan melihat wajah dan pakainnya. Anak juga dapat melihat warna pakaian yang digunakan tokoh, bentuk wajah para tokoh, ataupun suasana cerita dengan menggunakan bantuan ilustrasi cerita (Lukens, 2003).

Buku cerita bergambar berisi gambar, teks dan ilustrasi yang mendukung dalam menyampaikan sebuah cerita. Pemilihan buku cerita bergambar yang tepat akan memudahkan anak dalam menangkap maksud cerita. Buku cerita bergambar dapat digunakan dalam mengembangkan kecerdasan visual anak. Melalui penggunaan buku cerita bergambar memberikan kemudahan bagi anak untuk mengoptimalkan perkembangannya khususnya pada kecerdasan visual anak.

\section{METODE}

Penelitian ini menggunakan pendekatan dengan jenis quasi eksperimen dalam hal ini menggunakan kelas kontrol serta eksperimen. Cresswell (2016) menjelaskan bahwa penggunaan kelas eksperimen dan kotrol tidak dapat memasukan partisipan secara acak ke dalam dua kelompok. Tujuan utama dalam penelitian eksperimen adalah menguji dampak ataupun efek dari suatu perlakuan terhadap hasil penelitian, penelitian tersebut dikontrol oleh faktor lain yang dimungkinkan dapat berpengaruh terhadap hasil penelitian (Cresswell, 2016).

TK Pringwulung Yogyakarta menjadi tempat dilakukannya penelitian. Penelitian ini bertujuan untuk menggali dampak atau pengaruh dari penggunaan buku cerita bergambar terhadap kecerdasan visual anak usia empat sampai lima tahun. Dalam penelitian ini, kelompok eksperimen diberikan intervensi berupa pelibatan media buku cerita bergambar, sedangkan untuk kelas kontrol melibatkan teknik pembelajaran konvensional. Subjek penelitian berjumlah 40 anak yang terdiri dari 20 anak untuk kelas eksperimen dan 20 anak untuk kelas kontrol. Subjek diambil melalui teknik purposive sampling dengan kriteria bahwa kelas ini dipilih karena memiliki karakteristik yang relatif sama dalam kualitas akademik dan rentang umur. Lembar observasi digunakan dalam proses pengumpulan data.

Materi yang digunakan dalam buku cerita berbentuk fabel dengan judul Semut dan Jangkrik. Selama penelitian ini berlangsung, kelas A mendapatkan treatment melalui penggunaan buku yang berjudul semut dan jangkrik. Metode konvensional dalam hal ini bercerita tanpa penggunaan media buku cerita digunakan pada kelas B. Pemberian treatment di lakukan sebanyak delapan kali pertemuan. Setiap pertemuan menggunakan buku cerita bergambar dan dilihat setiap perkembangan dari penggunaan buku cerita tersebut terhadap kecerdaan visual anak. Adapun dimensi kecerdasan visual yang diukur yaitu kepekaan terhadap bentuk, unsur bentuk, ukuran, komposisi, dan warna. Analisis data menggunakan t-test dengan bantuan software SPSS for Windows versi16.

\section{HASIL DAN PEMBAHASAN}

Kecerdasan visual merupakan salah satu kecerdasan yang penting bagi anak. Kecerdasan visual merupakan potensi individu dalam menangkap visual objek secara detail, dan menggunakan kecerdasan ini dalam melihat segala macam objek yang diamati. Berdasarkan penelitian terhadap kecerdasan visual anak menggunakan buku cerita bergambar, hasil perhitungan pengolahan data dilakukan dengan bantuan analisis uji- $t$ menggunakan program SPSS 16 for windows. Pengambilan keputusan menggunakan kriteria yaitu jika nilai signifikan diperoleh kurang dari 0,05 maka $\mathrm{H}_{0}$ ditolak. Oleh sebab itu, terdapat perbedaan yang signifikan antara rata-rata kelas kontrol maupun eksperimen. Hasil perhitungan uji- $t$ dapat dilihat di tabel 1 . 
Jurnal PG-PAUD Trunojoyo : Jurnal Pendidikan dan Pembelajaran Anak Usia Dini, Volume 7, Nomor 1, April 2020, hal $10-16$, ISSN : 2528-3553 (online), ISSN: 2407-4454 (print)

Tabel 1 Hasil uji t Independent Sampel

\begin{tabular}{|c|c|c|c|c|c|}
\hline \multicolumn{7}{|c|}{ Group Statistics } \\
\hline & kelas & N & Mean & Std. Deviation & Std. Error Mean \\
\hline $\begin{array}{c}\text { visual } \\
\text { intelegence }\end{array}$ & $\mathrm{A}$ & 20 & 85.55 & 9.139 & 2.044 \\
\cline { 2 - 6 } & $\mathrm{B}$ & 20 & 76.05 & 7.022 & 1.570 \\
\hline
\end{tabular}

Independent Samples Test

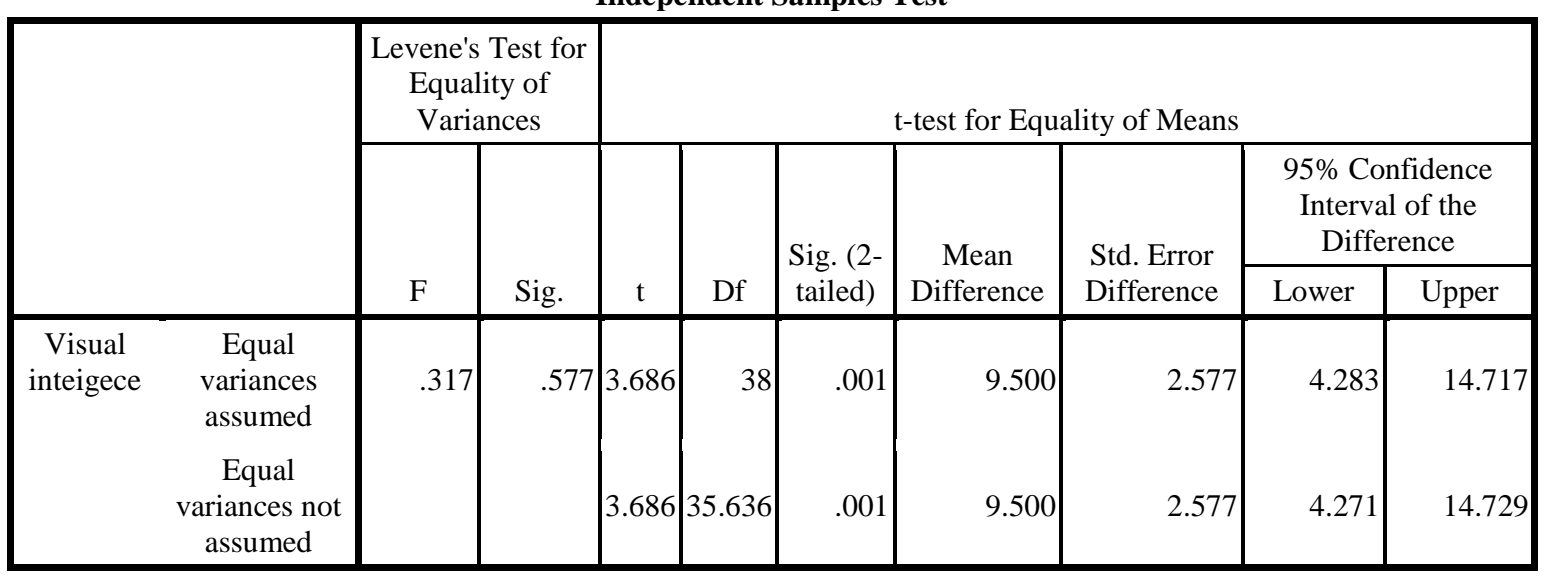

Hasil perhitungan pada tabel 1 menggunakan aplikasi SPSS 16 menujukan bahwa pada kecerdasan visual anak terdapat perbedaan antara kelas kontrol maupun eksperimen. Rangkuman dari hasil data posttest kecerdasan visual anak dengan menggunakan taraf kesalahan 0.05. Sehingga disimpulkan bahwa $\mathrm{H}_{0}$ ditolak sebab diperoleh hasil nilai Signifikansi $<a$ $(0,001<0,05)$. Hasil posttest kecerdasan visual anak menunjukan terdapat perbedaan antara kelas kontrol maupun eksperimen.

Hasil penelitian ini menunjukkan adanya pengaruh positif, serta signifikan dalam menggunakan buku cerita bergambar terhadap kecerdasan visual anak. Hasil ini menjelaskan bahwa anak usia empat hingga lima tahun yang diberikan pembelajaran menggunakan buku cerita bergambar mempunyai kecerdasan visual lebih tinggi dibandingkan dengan sebelum menggunakan buku cerita. Setiap aspek dari kecerdasan visual berupa kepekaan terhadap bentuk, unsur bentuk, ukuran, komposisi, dan warna memiliki progres kemajuan yang baik pada tiap pertemuan. Peningkatan kecerdasan visual tersebut terjadi melalui penggunaan buku cerita bergambar. Bermain sambil belajar akan semakin menyenangkan bagi anak. Anak menjadi subjek dalam pembelajaran di kelas. Proses belajar secara berkelompok maupun sendiripun dapat dilakukan.

Terdapat beberapa penelitian sebelumnya dan mendukung hasil penelitian ini. Sapitri (2018) yang menjelaskan bahwa adanya hubungan yang terjadi antara kecerdasan visual anak dengan kreativitas anak di TK Islam AlFalah di Jambi, persamaan dengan penelitian yang peneliti lakukan adalah sama-sama memfokuskan pada kecerdasan visual anak. Hasil penelitian selanjutnya yang disampaikan oleh Hakim (2017) yang menjelaskan bahwa terdapat peningkatan kecerdasan visual anak melalui permainan puzzle pada anak kelompok A di Sukaharo. Persamaan dalam penelitian ini adalah sama-sama meneliti tentang kecerdasan visual dan melalui penggunaan media visual. Penelitian Amelia (2015), hasil penelitiannya menunjukan bahwa terdapat pengaruh pembelajaran kindergarten watching terhadap stimulasi kecerdasan visual spasial dan kinestetik anak. persamaan penelitian ini dengan peneliti yakni sama-sama meneliti tentang kecerdasan visual, dan bedanya adalah 
Jurnal PG-PAUD Trunojoyo : Jurnal Pendidikan dan Pembelajaran Anak Usia Dini, Volume 7, Nomor 1, April 2020, hal $10-16$, ISSN : 2528-3553 (online), ISSN: 2407-4454 (print)

pada penggunaan stimulasi. Peneliti menggunakan media buku cerita bergambar sedangkan penelitian yang dilakuakn oleh Amelia menggunakan metode pembelajaran.

Hasil penelitian ini diharapkan orangtua, guru dan lingkungan di sekitar anak dapat membangun lingkungan visual yang baik bagi perkembangan kecerdasan visual anak, selain itu pemberian stimulasi yang tepat dapat mengoptimalkan perkembangan anak.

\section{SIMPULAN}

Pada hasil penelitian ini, menunjukan bahwa pemberian stimulasi yang tepat dapat meningkatkan kecerdasan visual anak pra sekolah. Hal ini dijunjukan berdasarkan hasil nilai Sig < a $(0.001<$ 0.05). Hasil penelitian ini membuktikan bahwa dengan memberikan rangsangan ataupun stimulasi yang tepat, dalam hal ini berupa penggunaan media buku cerita maka anak dapat meningkatkan kecerdasan visualnya. Lingkungan yang baik akan membentuk dan mengoptimakan potensi anak. Untuk mengembangkan kecerdasan visual anak dapat dilakukan dengan cara membangun lingkungan visual bagi perkembangan kecerdasan visual anak, selain itu pemberian stimulasi yang tepat akan mendukung dan membimbing perkembangan kecerdasan visual dalam setiap aktivitas yang dilakukan oleh anak. Hasil penelitian ini dapat digunakan oleh guru, orangtua, maupun praktisi pendidikan agar dapat memberikan stimulasi yang tepat dan optimal dalam perkembangan kecerdasan visual anak usia dini.

\section{DAFTAR PUSTAKA}

Amelia, L. (2015). Stimulasi kecerdasan visual-spasial dan kecerdasan kinestetik anak usia dini melalui metode kindergarten watching siaga bencana gempa bumi di PAUD Terpadu Permata Hati Banda Aceh. ISSN 2086-1397. Volume VI. No. 2.
Armstrong, T. (2009). Multiple intelligence in the classroom. America: present a variety of view points

Biddle, K.A.G., Nevarez, A.G., Henderson, W.J.R., \& Vallero-Kerrick, A.(2014). Early childhood education becoming a professional. Printed in USA: SAGE Publications, Inc,

Bower, V. (2014). Developing early literacy 0 to 8 from theory to practice. London: Sage publication L.td.

Brewer, J.A. (2007). Introduction to early childhood education preschool through primary grades: sixth edition. America: Person Education.

Cresswell, J. W. (2016). Research design pendekatan metode kualitatif, kuantitatif dan campuran edisi keempat. (Terjemahan Achmad Fawaid \& Rianayati K.P). Yogyakarta: Pustaka Pelajar. (edisi asli diterbitkan tahun 2014 oleh SAGE Publication, Inc.

Gardner, H. (2013). Multiple intelligence. Tanggerang selatan: Interaksara.

Hakim, A.(2017). Upaya meningkatkan kecerdasan visual spasial melalui permainan puzzle pada anak kelompok A di TK Aisyiyah Pabelan Kartasura Sukoharjo tahun ajaran 2016/2017. Surakarta: Universitas Muhammadiyah Surakarta.

Juli,Santi Putri. (2014). Meningkatkan Kecerdasan Visual-Spasial Anak Usia Dini dengan metode Bermain Building Block Pada Kelompok B6 di TK Dharma Wanita Persatuan Prov insi Bengkulu. Bengkulu : Univesitas Bengkulu.

Kotaman, H., \& Balci, A. (2016). Impact of storybook type on kindergarteners' storybook comprehension. Early Child Development and Care, http://dx.doi.org/10.1080/03004430.201 6.1188297 ,

Lenhart, J., Lenhard, W., Vaahtoranta, E., \& Suggate, S. (2017). Incidental vocabulary acquisition from listening to stories : a comparison between readaloud and free storytelling approaches. Educational Psychology, 1-21. https://doi.org/10.1080/01443410.2017.1363 377.

Lucy. (2010). Mendidik sesuai minat dan bakat anak. Jakarta : Tangga pustaka. 
Jurnal PG-PAUD Trunojoyo : Jurnal Pendidikan dan Pembelajaran Anak Usia Dini, Volume 7, Nomor 1, April 2020, hal $10-16$, ISSN : 2528-3553 (online), ISSN: 2407-4454 (print)

Lukens, J. R. (2003). A critical handbook of children's literature. United States of America: Pearson Education, Inc.

Machado, J. M.(2013). Early childhood experiences in language arts early literacy (10th ed). Wadsworth: Cengage Learning.

Mallet, M.(2010). Choosing and using fiction and nonfiction 3-11: a comprehensive guide for teachers and student teachers (1st ed). New York: Routledge.

Mantei, J. \& Kervin, L. (2014). Interpreting the images in a picture book: students make connections to themselves, their lives and experience. English Teaching: Practice and Critique. Vol. 13, No. 2 pp. 76-92. http://education.waikato.ac.nz/research/files/ etpc/files/2014v13n2art5.pdf.

Mitchell, D. (2003). Children's literature an invitation to the world. Boston: Peaarson Education, Inc.

Musfiroh, T. (2005). Bercerita untuk anak usia dini. Jakarta: Departemen Pendidikan Nasional, Direktorat Jenderal Pendidikan Tinggi, Direktorat Pembinaan Pendidikan Tenaga Kependidikan dan Ketenagaan Perguruan Tinggi.

Musfiroh, T. (2005). Pengembangan Dasar Majemuk. Jakarta:Universitas Terbuka.

Noorlaila, I. (2010). Panduan lengkap mengajar PAUD: Kreatif Mendidik dan Bermain Bersama Anak. Yogyakarta: Pinus Book Publisher.

Reed, H. C., Hurks, P. P. M., Kirschner, P. A., \& Jolles, J. (2015). Preschoolers' causal reasoning during shared picture book storytelling : A cross-case comparison descriptive study. Journal of Research in Childhood Education, 29: 367-389, http://www.doi.org /10.1080/02568543.2015.1042126.

Sapitri, N.(2018). Hubungan antara kecerdasan visual-spasial dengan kreativitas anak di TK Islam Al-Falah kota Jambi. Jambi. Universitas Jambi.

Scull, J., Louise, P., \& Raban, B. (2013) Young learners: Teachers' questions and prompt as oppurtunities for children's language development. Research in early childhood, vol 7 No.1, 69-91. Retrieved from http://research.monash.edu/en/publications/y oung-learners-teachers-questions-andprompts-as-opportunities-fo.

Suyadi. (2010). Psikologi belajar pendidikan anak usia dini. Yogyakarta: Pedagogia.

Suyanto, S.(2005). Dasar-dasar pendidikan anak usia dini. Yogyakarta: Hikayat Publishing.

Toha-sarumpaet, R. K. (2010). Pedoman penelitian sastra anak: edisi revisi. Jakarta: Buku Obor.

Tompkins, G.E., \& Hoskissons, K. (1995). Language arts: Content and teaching strategies (3rd ed.). New York: Mac Millan Publishing Co.

Williams, R.B. (2002). Multiple intelligences for differentiated learning. America: Corwin Press.

Yaumi, M. (2012). Pembelajaran berbasis multiple intelligence. Jakarta: Dian Rakyat.

Yus, A. (2011). Model pendidikan anak usia dini. Jakarta: Kencana. 